\title{
Students' Perception of the Use of Google Classroom in Flipped English Learning during the COVID-19 Pandemic
}

\author{
Liya Astarilla Dede Warman
}

\author{
STMIK-AMIK Riau, Pekanbaru, Riau, Indonesia. \\ *Corresponding author. Email: liya@stmik-amik-riau.ac.id
}

\begin{abstract}
This research aimed to investigate the students' perception of the use of Google Classroom in flipped English learning during the COVID-19 pandemic. This study was descriptive quantitative and qualitative research. The data were collected through the questionnaire and interview. The participants of this study were 227 university students in Pekanbaru, Riau, Indonesia. The findings of this research revealed that the participants generally had a positive perception of the use of Google Classroom in flipped English learning during the COVID-19 pandemic. The majority of the participants agreed that Google Classroom was easy to use and effective in flipped English learning. Furthermore, the participants were interested and motivated in using Google Classroom for flipped English learning during the pandemic. They felt easier to comprehend the English material in flipped learning through Google Classroom. Besides, it could increase the students' collaborative learning and also develop their autonomous learning. However, this research also showed several challenging issues faced by the participants in flipped learning through Google Classroom, namely: the limited access to the internet connection for the participants who lived in rural areas, the lack of physical interaction, the distractions at home, the expensive cost of internet data package and the lack of compatible smartphones of the unprivileged participants in online learning during the pandemic. Nevertheless, the positive aspects of the use of Google Classroom gave a contribution to enrich flipped English learning in the emergency online learning during the COVID-19 pandemic. In conclusion, the use of Google Classroom in flipped learning could improve students' interest and motivation in learning English that continued to their learning outcome during the pandemic.
\end{abstract}

Keywords: Students' perception, Google Classroom, flipped English learning, COVID-19 pandemic

\section{INTRODUCTION}

The COVID-19 pandemic or coronavirus disease has spread all over the world and interrupted many dimensions of human life, including the education system in Indonesia. The COVID-19 pandemic was confirmed to spread in Indonesia on $2^{\text {nd }}$ March 2020. In order to reduce the transmission of this virus, the government with WHO ordered physical distancing, movement restrictions, work from home, and study from home. The Ministry of Education and Culture issued Circular Letter Number 4 in 2020 regarding to the implementation of education system in the emergency of COVID-19 namely to conduct teaching and learning via online learning. Furthermore, since the beginning of April 2020 when the COVID-19 was identified spreading in Pekanbaru, Riau, Indonesia, the local government imposed almost all of schools and universities were nearly total closured and implemented online learning where the teaching and learning activities held online in preventing the transmission of this virus. Due to this condition, remote learning or online learning is applicable for education in the COVID-19 epoch. It means that online learning or distance learning was not an option, but it was a necessity system during the pandemic. The teacher and the students were forced to use online teaching and learning or distance education to protect and save their life from the virus ferocity. Obviously, there is a paradigm shift from face to face (offline learning) to fully online learning model.

Online learning or distance learning is not a new education system. It was already used at several universities and colleges in the late eighties and the nineties of the last century due to its benefits. By the twenties century with the proliferation of Information and Communication Technology, online learning have been 
integrated into the education system all over the world at all level of education. It has been applied for many teacher and researchers to enhance their teaching and learning process. Distance learning is defined as the learning process where the students may not be physically present at the school [1]. In addition, Roffe defines online learning as a method of teaching where the teacher and the students are physically disparted and employs a combination of technologies such as audio, video, computer and internet in learning. It is an instrument that makes the teaching and learning activities more student-centered, innovative and resilient. The students have learning experiences through the synchronous or asynchronous environment by using several devices such as smartphone, laptop, and computer [2] [3]. It has a great number of strengths than traditional educational settings [4]. In short, it has a dominating aspect of remote learning which is freedom from constraint namely, time, space, content, access, and medium. Furthermore, online learning also has been applied in several countries that experienced natural disaster where it lead to the closure of schools and universities namely, earthquakes in Italy (2016), hurricane in New Zealand (2011), Flood in Nepal (2017), hurricane in the United States (2017), etc. These hazards disrupt people life, the schools and colleges building collapsed, even the road had crumbled, and could not conduct the face to face meeting at that time. However, they still continue the education system by using remote learning strategies in teaching and learning activities. Online learning could help education system amid the disasters (Dhawan, 2020). Richards et al. said that when disasters and crises happened, schools and universities must be resilient and look for the new ways to continue teaching and learning process [5]. These conditions are almost the same with the condition in Indonesia, even though the pandemic disrupt education system, but the education is unstoppable. The education system changed into online learning. It means that the advantages of online learning or distance learning can help the teacher and the students in the teaching and learning process amid the pandemic.

Before the pandemic happened and the policy of home-based learning issue, the researcher taught the student face to face in the classroom and also via online learning or blended learning. The researcher conducted teaching and learning activities mostly at campus and implemented blended learning only for several meetings to support the teaching and learning process. She conducted blended learning by using several application and web system such as, WhatsApp, Google Classroom, Moodle, Duolingo, etc. It means that the lecturer did not teach the students fully online learning before the pandemic. In fact, after the pandemic outbreak in Indonesia, the government through the Ministry of education ordered that teaching and learning activities must be done via online learning, the researcher shifted the teaching and learning activities to fully online learning.

During home-based learning, there were several methods used by the researcher to conduct the teaching and learning activities. At the first semester, the researcher combined an asynchronous and synchronous approach namely: Google Classroom and Google Meet or Zoom. Teaching materials and assignments were uploaded and shared by the lecturer on Google Classroom. The teaching and learning activities were conducted once a week or 100 minutes for each meeting. According to the researcher's experience and observation in teaching the students in the early of COVID-19 pandemic, the students have difficulties to adapt and comprehend the English lesson in the new learning environment. The students need more time to learn English, 100 minutes for each session was not enough. In fact, the teaching method used by the lecturer was not effective for the teaching and learning process during the pandemic. The teaching and learning process along with the outcomes were not as expected.

Furthermore, after learning several methods and pilot studies of teaching, the researcher considered to change the method of teaching by implementing flipped learning through Google classroom for the next semester. There were several studies conducted by the previous researchers showed the effectiveness and the positive aspects of using Google Classroom and flipped learning before the pandemic. Although several studies have been investigated in flipped learning and Google Classroom, the quantitative and qualitative study in flipped English learning through Google Classroom during the pandemic was still limited and needed. Thus, after conducting flipped English learning through Google Classroom for one semester during the pandemic, the researcher wanted to investigate the students' perception of the use of Google Classroom in flipped English learning during the pandemic. This research aimed to investigate the students' perception of the use of Google Classroom in flipped English learning during the COVID-19 pandemic.

\subsection{Flipped Learning}

Flip learning has developed and implemented rapidly in diversity of educational contexts during the last decade [6]. Many researchers have given their definition about flipped classroom. Van Alten et al. and Hew \& Lo defined flipped classrooms as students learn instructional materials such as by watching lecturer's videos or reading materials before class and applying the instructional materials into active learning activities namely working on problem-solving assignments or discussion during the class [7] [8]. Then, Bishop \& Verleger asserted flipped learning classroom as an educational method consisted of two phases: direct computer-based instruction before coming to the classroom and active learning activities in the classroom [9].

The idea of flipped learning model was stated by King in 1993. Then, in 1996 the first model of flipped classroom was implemented by Prof. Eric Mazur from Harvard University to his students in 1997 . He points out that the learning processes start before coming to school and elaborate it more in-depth in face to face meetings at school. He asked his students to take notes related to the readings materials or books before having the class. Afterward, he held a discussion platform by generating questions related to the topics and had active learning processes [10], [11], [12]. The advances of ICT have been influencing the evolution of flipped classroom in 2000s. It enhanced the flipped classroom by integrating internet and technology during teaching and learning processes. Many researchers had contributed to flipped classroom approach remarkably, namely; Baker, Lage, Platt and Treglia in 2000 who applied flipped learning by using the computer. They 
gave presentation via computer or VCRs out of classroom to replace in the classroom. Then, the flipped learning classroom have been widely growing by using videos tutorials to enhance teaching and learning activities as conducted by Khan in 2004 and Bergmann and Sams in 2007 [10], [13]. Several studies have showed the effectiveness of the implementing flipped learning classroom in improving students' learning achievement and this approach also affected positively the students' attitude and motivation in learning activities. Mubarok et al. found that flipped classroom model could improve the university students' achievement of English as a Foreign Language especially on their writing skills. Then, Hung reported that flipped classroom improved students' learning outcomes and increase their satisfaction and participation in the learning activities [15]. Next study was done by $\mathrm{Yu}$ in 2019 found that the majority of the participants had positive attitudes and motivation of the use of flipped learning in learning English. In other words, flipped learning have been proven could improve the students' learning outcomes and motivation in learning English.

\subsection{Google Classroom}

Actually, there are several applications and learning management system of education could be used for flipping classroom, but the researcher decided to use Google Classroom in this study due to several reasons. First, she had conducted quasy-experimental study at a private college in Pekanbaru, Riau, Indonesia at the first semester of the 2019/2020 academic year. This study found that Google Classroom was effective in improving the students' English achievement [16]. But, the differences were in the previous study the researcher used Google Classroom in normal condition or before the COVID-19 pandemic epoch and only administered to the 68 participants. Then, in the present study the participants were 227 students and the teaching and learning activities were conducted fully online amid the pandemic condition. Second, Google classroom is flexible and accessable via smartphone and computer. Third, after implementing several learning management system or applications, the researcher assumed that Google Classroom is the most appropriate learning management system for her and the students' needs in flipped learning during the pandemic.

Google Classroom was developed by Google in 2014 for academic purposes to support teaching and learning activities. This application is easy to use, it does not take too much memory on a smartphone and can help the teachers and students keep on the lesson's track. Google Classroom is a newly recognized, innovative, and considered as one the best platforms for teaching and learning [17]. Janzen and Syakur et al. point out that there are several benefits of using Google Classroom [18], [19]. First, Google Classroom is easy to use and simplify the instructional interface for assignment submission and also for communication with the students through announcements, emails and notifications. Second, it is evolved to skimp time since it can integrate Google docs, spread sheet, slides, feedback, grading, and formative assessment. Third, it is flexible and useable for teachers and students in face to face learning and online learning environment. Fourth, it is free Learning Management System. Fifth, it improves students' cooperation and communication. Sixth, Google Classroom has centred data storage where the students and the teacher can check the assignments in a certain folder or save teaching materials in a cloud. The last, it is mobile-friendly and the students can access it at anywhere and anytime. They accede that Google Classroom was effective to support the teaching and learning process via online learning. By considering the aforementioned problems and the shifting of the teaching and learning activities via online learning amid the pandemic, the researcher assumed that the use of Google Classroom in flipped English learning could help the students in learning and teaching activities during the COVID-19 pandemic.

\section{METHOD}

\subsection{Research Design}

This study was descriptive quantitative and qualitative research. This research used mixed-method design in collecting the data, which is conducted by combining both quantitative and qualitative data at the same time [20]. Using mixed-method method is particularly powerful in investigating someone's study and the results are more legitimate since they have been corroborated through multiple data collection methods [21]. The quantitative study was applied to explore the students' perception of the use of Google Classroom in the flipped learning during the pandemic. Meanwhile, the qualitative design was conducted to examine the students' experiences in flipped learning classroom by using Google Classroom during the COVID-19 pandemic. The students used Google Classroom in flipped classrooms in teaching and learning process for one semester or 16 meetings. The participants were invited to answer the online questionnaire via Google Form to investigate their perception of the use of Google Classroom in flipped learning at the end of the semester. Furthermore, the selected participants (15 students) were invited to semi-structure interview to follow up the questionnaire results. The interview was designed to present deeper insights into the participants' perception of the use Google Classroom in flipped learning during the pandemic that emphasized their experiences from the benefits to the challenges of using Google Classroom amid the pandemic. To analyze the quantitative and qualitative data that have different types, triangulation design was used in this study. Next, the data were interpreted comprehensively [21]. The chart of the method design was presented in figure 1 .

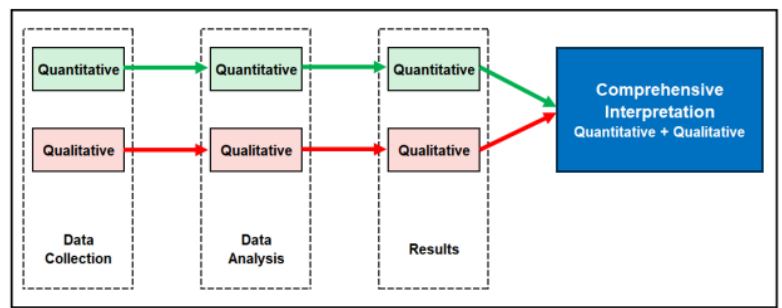

Figure 1 The Triangulation Method Design

\subsection{Participants}

This study involved 227 students from several universities in Pekanbaru, Riau, Indonesia who took English course as a compulsory subject. They were in their 
second and sixth semester of the 2020/2021 academic year, majoring in computer science, information system, information technology and economics. They were consisted of 177 male and 50 female students. Their age ranges were from 19-30 years old. They were chosen by using purposive sampling method. All of the participants participated in the quantitative study and 15 of them participated in qualitative study or in-depth interview. They were purposively selected based on their active participation and location during the teaching and learning process in flipped classroom through Google Classroom in one semester. The researcher considered to choose the participants that always actively participated in the flipped learning and come from several different locations or areas to explore and elaborate the participants' experiences in flipped learning during the pandemic. Before the pandemic occurred, the students lived near the campus area in Pekanbaru city. Since the pandemic outbreak and there was regulation from the local government namely physical distancing and movement restrictions, almost of the participants went back to their hometown and learning from their home. The participants come from several provinces and districts in Indonesia such as Riau, Riau Islands, North Sumatera, and West Sumatra.

\subsection{Instruments}

Two instruments were used in this study. The quantitative data were obtained through the questionnaire and the qualitative data were obtained through semistructure interview. The questionnaire was developed by the researcher based on the related literatures and the previous studies. She adapted and adjusted the questionnaire based on the ground theory of Technology Acceptance Model TAM by Venkatesh \& Davis, Gunduz \& Ozcan and Aljaraideh studies so that it was more relevant to the participants' learning experiences and the purpose of the research. The questionnaire composed of two parts [22], [23], [24]. The first part included demographic information of the participants namely their age, gender, semester, major, location or address when they were participating in this study. The second part consisted of 20 items closed-questions, which were grouped under four elements of behavioural of orientation in technology diffusion in flipped learning including perceive of ease, perceived of usefulness, perceived the effectiveness and perceived attitude of the use of Google Classroom in flipped learning. The questionnaire items were written in English and Bahasa Indonesia to anticipate the language barrier among the participants and they understand the statements easily since the questionnaire were distributed via Google Form. Five-level Likert item was adopted in the questionnaire namely Strongly disagree, Disagree, Neutral, Agree, and Strongly Agree). The validity of the questionnaire was checked and validated by three English language-teaching experts. They examined and revised the confusing sentences then ensured the questions in the questionnaire were appropriate with the research objectives. Next, before distributing electronically the questionnaire to the participants, it was tested to thirty students to know the reliability of the questionnaire. The reliability of the questionnaire was verified by using Cronbach's Alpha correlation coefficient. The result was 0.82 and the result revealed that the questionnaire was categorized into high degree of reliability and reliable used in this study.

Furthermore, the qualitative data obtained from semi-structure interview consisted of open-ended questions. It provided the participants experiences and perception of the use of Google Classroom in flipped learning. They described their experiences and offered feedback from their perspectives of using Google Classroom in flipped learning during the pandemic namely; the benefits of using Google Classroom in flipped learning and the challenges of using Google Classroom in flipped English learning perceived by the students during the pandemic. The interview was video-recorded and taken by using Zoom application.

\subsection{Data Collection and Analysis}

After two data collection instruments were administered by the researcher, the data collected were analyzed both quantitatively and qualitatively. The quantitative data collected from through the questionnaire was analyzed statistically using SPSS version 22 . The quantitative data were analyzed using descriptive statistics namely mean, standard deviation, and percentage. Finally, the students' perceptions towards the use of Google Classroom in flipped learning during the pandemic were classified into several categories as mentioned in table 1.

Table 1. The scale of students' perception

\begin{tabular}{|l|l|}
\hline Range & \multicolumn{1}{c|}{ Category } \\
\hline $1.00-1.50$ & Very low/very negative \\
\hline $1.50-2.50$ & Low/negative \\
\hline $2.51-3.50$ & Moderate \\
\hline $3.51-4.50$ & High/positive \\
\hline $4.51-5.00$ & Very high/very positive \\
\hline
\end{tabular}

Furthermore, the qualitative data obtained from the interview was analyzed using content analysis through several steps [20]. First, the data were organized and prepared by the researcher. Second, the video-recorded was transcribed and the general information obtained from the interview was jotted down by the researcher. In addition, the data were coded based on the topics and presented by the researcher.

\section{FINDING AND DISCUSSION \\ 3.1. The Result of Quantitative Data}

The results from quantitative data showed that the majority of the students have positive perception of the use of Google Classroom in flipped learning English during the pandemic. Most of the means in each item were in high level. The results were presented in the following tables.

Table 2 shows that majority of the participants agree that Google Classroom is easy to access whether from mobile phone, laptop and computer at anytime and anywhere. It receives the highest mean from all of items in the questionnaire $(\mathrm{M}=4.43, \mathrm{SD}=0.76)$. The second highest mean from all of the items in the questionnaire, it is easy to upload or submit file, images, video which related to the course content via Google Classroom $(M=4.19, S D=0.91)$. Next, the participants also approve that it is easy to read materials or watch videos provided by the lecturer on Google Classroom $(\mathrm{M}=4.00, \mathrm{SD}=0.92)$. Then, more than $60 \%$ of the participants (the aggregated result of 'agree' 
and 'strongly agree') admit that Google Classroom is convenient to enrich flipped learning.

Table 2. Descriptive statistics of students' perceived of ease of using Google Classroom in flipped English learning

\begin{tabular}{|c|c|c|c|c|c|c|c|c|}
\hline \multirow{3}{*}{ No } & \multirow{3}{*}{ Item } & $\begin{array}{l}\text { Strougly } \\
\text { Disagree }\end{array}$ & Disagree & Neutral & Agree & $\begin{array}{c}\begin{array}{c}\text { Strougly } \\
\text { Agree }\end{array} \\
\end{array}$ & \multirow{3}{*}{ Mean } & \multirow{3}{*}{ SD } \\
\hline & & 1 & 2 & 3 & 4 & 5 & & \\
\hline & & $\%$ & $\%$ & $\%$ & $\%$ & $\%$ & & \\
\hline 1 & 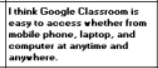 & 0,4 & 0.9 & 11.5 & 30 & 57.3 & 4,43 & 0,76 \\
\hline 2 & 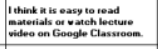 & 0.9 & 4.4 & 23.8 & 35.2 & 35.7 & 4,00 & 0,92 \\
\hline 3 & 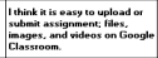 & 1.3 & 2.6 & 18.1 & 31.7 & 46.3 & 4,19 & 0,91 \\
\hline$\cdot$ & 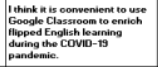 & 4.8 & 8.8 & 24.7 & 33.5 & 28.2 & 3,71 & 1,11 \\
\hline & 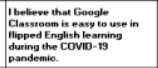 & 2.2 & 6.2 & 28.6 & 37.9 & 25.1 & 3,78 & 0,97 \\
\hline
\end{tabular}

Table 3 demonstrates that the results from questionnaire of students' perceived of usefulness of flipped learning through Google Classroom during the pandemic also at high level or positive. The results can be shown as follows:

Table 3. Descriptive statistics of students' perceived of usefulness of using Google Classroom in flipped English learning

\begin{tabular}{|c|c|c|c|c|c|c|c|c|}
\hline \multirow{3}{*}{ No } & \multirow{3}{*}{ Item } & $\begin{array}{l}\text { Strougly } \\
\text { Disagree }\end{array}$ & Disagree & Neutral & Agree & $\begin{array}{c}\begin{array}{c}\text { Strougly } \\
\text { Agree }\end{array}\end{array}$ & \multirow{3}{*}{ Mean } & \multirow{3}{*}{ SD } \\
\hline & & 1 & 2 & 3 & 4 & 5 & & \\
\hline & & $\%$ & $\%$ & $\%$ & $\%$ & $\%$ & & \\
\hline 6 & 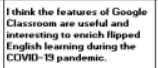 & 0.9 & 2.6 & 20.7 & 37 & 38.8 & 4,10 & $0,8 s$ \\
\hline , & 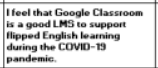 & 0.9 & 4.8 & 17.6 & 30.3 & 30.3 & 4,08 & 0,91 \\
\hline : & 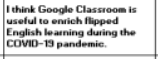 & 0.4 & 4.8 & 10.2 & 41.4 & 36,1 & 4,08 & 0,87 \\
\hline 3 & 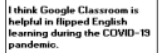 & 0.4 & 6.2 & 22,9 & 40.5 & 30 & 3,93 & 0,90 \\
\hline & 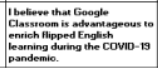 & 1.3 & 4.8 & 20.3 & 40.5 & 33 & 3,99 & 0,92 \\
\hline
\end{tabular}

Table 3 indicates that majority of the participants agree that Google Classroom features are useful and interesting to enrich flipped English learning during the COVID-19 pandemic $(\mathrm{M}=4.10, \mathrm{SD}=0.88)$. Then, more than $70 \%$ of the participants accede that Google Classroom is a good LMS for learning materials and watching the lecturer's video $(\mathrm{M}=4.08, \mathrm{SD}=0.91)$. In addition, they also approve that Google Classroom is useful and helpful to enrich flipped English learning during the pandemic $(\mathrm{M}=4.08$ and $\mathrm{M}=3.93)$. Finally, $73.5 \%$ of the participants believe that Google Classroom is advantageous to enrich flipped English learning amid the pandemic $(M=3.99$, $\mathrm{SD}=0.92$ )

Table below shows the participants' responses about the effectiveness of using Google Classroom in flipped English learning during the COVID-19 pandemic. The results can be revealed as following:
Table 4. Descriptive statistics of students' perceived of effectiveness of using Google Classroom in flipped English learning

\begin{tabular}{|c|c|c|c|c|c|c|c|c|}
\hline \multicolumn{9}{|c|}{$\because 8$} \\
\hline \multirow{3}{*}{ No } & \multirow{3}{*}{ Item } & $\begin{array}{l}\text { Strougly } \\
\text { Disagree }\end{array}$ & Disagree & Neutral & Agree & $\begin{array}{c}\text { Strongly } \\
\text { Agrre }\end{array}$ & \multirow{3}{*}{ Mean } & \multirow{3}{*}{ SD } \\
\hline & & 1 & 2 & 3 & 4 & 5 & & \\
\hline & & $\%$ & $\%$ & $\%$ & $\%$ & $\%$ & & \\
\hline " & 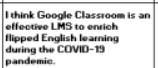 & 1.3 & 4.4 & 18.9 & 37 & 38,3 & 4,07 & 0,93 \\
\hline 12 & 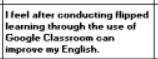 & 5.7 & 15,4 & 31,7 & 27.3 & 19.8 & 3,40 & 1,14 \\
\hline 13 & 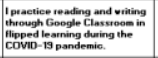 & 2.2 & 7.1 & 26.1 & 37.5 & 27 & 3,80 & 0,99 \\
\hline & 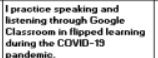 & 2,2 & 5.8 & 25,7 & э9,8 & 26.5 & 3,83 & 0,96 \\
\hline & 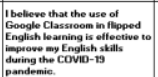 & 4.4 & 11.9 & 30,1 & 33,6 & 19.9 & 3,53 & 1,08 \\
\hline
\end{tabular}

Table 4 presents that $75.3 \%$ of the students agree that Google Classroom is an effective LMS to enrich flipped English learning during the pandemic ( $M=4.07$, $\mathrm{SD}=0.93)$. Amongst the items in the questionnaire in which item number 12 has the lowest average score $(M=3.40$, $\mathrm{SD}=1.43)$. The mean score of item number 12 is at moderate level. Then, more than $60 \%$ of the participants admit that they practice their four skills namely reading, writing, speaking, and listening through Google Classroom in flipped English learning. Besides, the participants believe that the use of Google Classroom in flipped English learning is effective to enhance their English skills $(\mathrm{M}=3.53, \mathrm{SD}=1.08)$.

Table 5 indicates the responses of the participants about their attitude in flipped English learning through Google Classroom during the pandemic affected their attitude $(70-77 \%$ of the participants). The results can be shown as follows:

Table 5. Descriptive statistics of students' perceived of attitude of using Google Classroom in flipped English learning

\begin{tabular}{|c|c|c|c|c|c|c|c|c|}
\hline \\
\hline \multirow{3}{*}{ No } & \multirow{3}{*}{ Item } & $\begin{array}{c}\text { Strongly } \\
\text { Disagree }\end{array}$ & Disagree & Neutral & Agree & $\begin{array}{c}\text { Strougly } \\
\text { Agree }\end{array}$ & \multirow{3}{*}{ Mean } & \multirow{3}{*}{ SD } \\
\hline & & 1 & 2 & 3 & 4 & 5 & & \\
\hline & & $\%$ & $\%$ & $\%$ & $\%$ & $\%$ & & \\
\hline 16 & 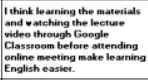 & 0.9 & 5.3 & 23 & 35 & 35.8 & 4,00 & 0,94 \\
\hline$n$ & 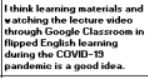 & 2,2 & 1,8 & 19 & 39,8 & 37,2 & 4,08 & 0,91 \\
\hline 18 & 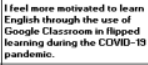 & 2.2 & 4.9 & 26.1 & 38.1 & 28.8 & 3,86 & 0,96 \\
\hline 19 & 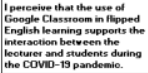 & 1.3 & 4.9 & 24.8 & 38.1 & 31 & 3,92 & 0,93 \\
\hline 20 & 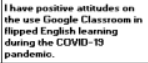 & 1.8 & 6.2 & 21.2 & 35.8 & 35 & 3,96 & 0,99 \\
\hline
\end{tabular}

The findings from table 5 reflect that $70.8 \%$ of the participants have positive attitude of the use of Google Classroom in flipped English learning during the COVID19 pandemic. They also agree that doing flipped learning by learning materials and watching the videos through Google Classroom before online meeting (synchronous learning) is a good idea and makes learning English is easier. The participants approve that Google Classroom supports the interaction between the participants and the lecturer $(M=3.92, S D=0.99)$. Furthermore, they accede they feel motivated to learn English in flipped learning through Google Classroom during the COVID-19 pandemic $(\mathrm{M}=3.86$, SD-0.93). 
From the findings of quantitative data, the researcher concluded that the majority of the participants have a positive attitude towards the use of Google Classroom in flipped learning during the pandemic. It was indicated by the means from the students' responses in the questionnaire was categorized as positive level. These findings were in line with some researchers' findings. Shahani et al. found that their EFL learners had a positive attitude towards flipped learning via Google Classroom. The learners also agreed that it was helpful using flipped learning via Google Classroom [25]. This finding also coincided with Beaumont's study that reported Google Classroom has the criteria of flipped learning. The result of his study showed that the students' perspective of the use of Google Classroom in learning was very positive [26].

\subsection{The Result of Qualitative Data}

The researchers found several responses from the selected participants related to the questions in the interview. Actually, there were questions asked by the researcher to every participant in the interview, namely; the benefits and the challenges of using Google Classroom in flipped learning amid the pandemic. The researcher interviews 15 participants based on their location and participation during teaching and learning process via Google Classroom in flipped learning in one semester. So, the researcher could explore and elaborate the participants' experiences of using Google Classroom in flipped learning during the COVID-19 pandemic.

\subsubsection{The benefit of using Google Classroom in} flipped learning during the COVID-19 pandemic

Dealing with the students' point of views in the interview, several findings were obtained by the researcher. There were several prominent opinions regarding to the benefits of using Google Classroom during this pandemic. The results from the interview are presented as follows.

\subsubsection{Facilitate the students in learning English \\ Several students reported that using Google} Classroom in flipped English learning amid the pandemic helped them in teaching and learning processes. The features of Google Classroom were convenient to use and facilitate them in learning English during the pandemic. It was also flexible to use because they can learn English anywhere and anytime. The responses of the students as follows:

"I think Google Classroom is the best and the easiest education application for learning English if I compare with the other applications that we have ever used during the pandemic. The features of Google Classroom are convenient and easy to use. It is suitable with the flipped learning activities. I also can collaborate and interact with my friends using Google Classroom. Next, the server of Google Classroom is stable and I have never got problem while using Google Classroom in flipped learning during this pandemic." (Novri, Pekanbaru Riau) "I think Google Classroom is help us in learning English during the pandemic. I like using Google Classroom because it has the complete features, namely; storage, place for our assignment, quiz, attendance list, materials, documents, videos, etc. Furthermore, there is a place for our grades too where the lecturer gives score and feedback. That is really great because I know my mistakes and what part of the assignment should be improved. This process is really fair." (Fandi, Pasir Pengaraian, Riau).

"I like Google Classroom because it has storage where I can save all materials, videos, documents or files. Even though I do not download the files since my phone has limited storage. I still can open all documents anytime via Google Classroom.” Febri, Kuantan Singigi, Riau).

"I like learning trough Google Classroom in flipped learning due to its flexibility. I can learn English anywhere and anytime. I think Google Classroom really facilitate us in learning English from home due to the restriction of movement and home-based learning policies from the local government. So, I just stay and study from my hometown." (Ahmad, Payakumbuh, West Sumatera)

Based on the participants' responses above, it can be said that the features of Google Classroom in flipped English learning could facilitate the students' English learning during the pandemic. This finding also supported by Iftakhar who said that Google Classroom provides a set of powerful features that help the teacher and students in accessing materials, saving time, organizing files, improving communication and integrating with other application [27]. In addition, the features of Google Classroom are useful in simplifying the teaching and learning activities for both teacher and student [28].

\subsubsection{Increase the students' collaboration and motivation}

Some of the students felt that after conducting flipped learning through Google Classroom, it could enhance their collaboration and also their motivation in learning English. It was also found that there were several factors that increased their collaboration and motivation of using Google Classroom during this pandemic namely the features of Google Classroom, the materials or videos given by the lecturer for flipped learning on Google Classroom, and the lecturer's presence. According to Syakur Google Classroom has one of the sophistication benefits that it can be used together in groups collaboratively [29]. This condition triggers the students' motivation in learning activity, due to its peer effect. The students may learn each other and improve their ability together [30]. In addition, Crawford and Keeler also agree that Google Classroom application facilitates and encourage collaborative learning between students [31], [32]. Besides, it facilitates the interaction between teacher and student. The responses from the students as following:

"I feel by using Google Classroom in flipped learning, it can help and motivate me in learning English from home. The application is easy to use, it has great features, and I can interact with my lecturer privately. Besides, I can collaborate and work together with friends through Google Classroom. It can enhance my motivation when I can learn with my friends. I think in this situation which we cannot study at campus, this kind of learning is beneficial to improve my English. So, my friends and I will not leave behind due to this pandemic 
Anyway, to be honest, I feel my English skills' improvement is not as good as when I was learning in the face to face learning at campus. However, as we are not allowed to conduct face to face teaching and learning at campus, I think it is the best way to continue our education in this pandemic. Finally, I can keep my health and avoid from the COVID-19 diseases." (Laili, Pariaman, West Sumatera)

"I think what I like the most from flipped learning through Google Classroom beside it features, I can interact and collaborate with my friends in doing the assignment. I can learn the materials first and have a discussion with my friends. It can help me in improving my English and I feel motivated learning through Google Classroom during this pandemic." (Sari; Siak, Riau)

"I like how my lecturer delivers the materials via Google Classroom in the flipped learning during in this semester. First, she is friendly, supportive and always motivates us to learn English before and during the class meeting. Second, the materials given by the lecturer on Google Classroom are interesting and fun. She makes her own video for us which explain about the material, then uploaded it on the Google Classroom. These videos really help us in understanding the lesson. Besides, when I do not understand or I want to consult with her privately via chat, she always response to my questions nicely.” (Dheni, Batam, Riau Islands)

Then, the unique response from an introverted student found by the researcher that he preferred to interact and collaborate with his friends via online or Google Classroom than face to face meeting in the classroom since he has low of self-confident.

"I like learning English in flipped learning through Google Classroom because I am an introverted person. I feel more motivated learning English in online flipped learning. I feel comfortable when I share my opinion via online because I feel nervous when I must speak face to face in the classroom. Now, I can interact with my friends and my lecturer via Google Classroom or during meeting. Even though learning through Google Classroom is not as detailed as offline learning but when I am still confused with the materials, I can watch the lecture video several times and I can ask my lecturer privately. I also enjoy having discussion via online with my friends. This way is better for me than I ask them directly because I am shy.” (AR, Tembilahan, Riau).

\subsubsection{Help the students in learning English}

The students confirmed that the activities in flipped learning through Google Classroom could help them in understanding the material. The researcher concluded that they got better understanding after conducting flipped learning through Google Classroom than did not. It seemed that watching the lecture video before having online meeting helped the students in understanding the material before having online meeting. They also looked have more self-confident during the class. This finding is in line with the study of Schmidt and Ralph who found that learners will be ready to overcome their problems since they are well prepared by watching the lecture video before coming to the class [33]. Furthermore, the activities of flipped learning will make students more motivated and confident in the classroom because they have already prepared before coming to class [12]. The responses of the students in the interview as follows:

"I think using Google Classroom in flipped learning is interesting and fun. I can watch my lecturer's video before class meeting through Google Classroom. I can better understand the material through Google Classroom in flipped English learning than before when we did not apply flipped learning. I can repeat or replay the videos on Google Classroom if I forget about something related to the lesson. It really helps me before having quiz and eaxmination, I re-watch the lecturer's explanation on the videos." (Seno, Rantau Prapat, North Sumatera)

"I think learning English via Google Classroom in flipped learning is better than the previous semester learning method. Because when I do not understand with the materials, I still can replay the lecture video and discuss with my lecturer. I and my friends also have more time to have a whole class discussion during the online class meeting. It can enhance my motivation in learning English.” (Candra, Rengat, Riau)

"What I like the most from Google Classroom in flipped English learning is I can learn the materials or watch the videos from my lecturer before the class meeting. I think this method makes me easy to understand the lesson given. Besides, I think my friends and I have more time for discussion during the class meeting after using Google Classroom in flipped learning." (Diana, South Lampung)

"I like flipped learning English through Google Classroom during this pandemic because I have to work to help my parent to earn money. Sometimes, I missed my English class, but I still can learn the lesson by watching my lecturer's video on Google Classroom. Then, I think using Google Classroom in flipped learning can enhance my knowledge of English and technology. I think my lecturer is attentive with my condition, she considered my problems in online learning." (NN, Pekanbaru, Riau)

"I think after using Google Classroom in flipped learning, I have more time to understand and engage with my friends and my lecturer. However, if I compare to face to face meeting in the classroom, of course, having online flipped learning through Google Classroom is not better than blended learning or face to face meeting at campus. Anyway, this method can help me in learning English during this pandemic." (Abdul, Natuna, Riau Islands).

\subsubsection{Develop the student's autonomous learning}

The other students explained that using Google Classroom in flipped English learning could develop their autonomous learning. In flipped learning, students or adult learners can organize their own learning. They perform their own learning along with the responsibility since they can learn and watch the lecture video individually before having the class meeting [34]. The students' opinion in the interview as following: 
"I think using Google Classroom in flipped learning amid the pandemic help me in learning English more independently. I also learn to manage my study time well. Google Classroom helps me in organizing my study during this pandemic. When I get notification in my email such as the materials and the assignment shared by the lecturer, I will do it immediately. Then, I submit it before the due date of the assignment. So, the assignment will not pile up. (Nanda, Belilas, Riau)

"I think after using Google Classroom in flipped English learning I can learn more independently because I read and learn the material by myself before the schedule. I learn to be more responsible in learning and doing my assignment. I realized that during this pandemic, as a student I should be aware to learn English by myself at home because if I do not learn English diligently, I cannot improve my English well." (Nana, Petapahan, Riau)

From these findings, the researcher concluded that during the pandemic the university students developed their autonomous learning. They learned by themselves without the parental involvement. It means that they were able to manage their study time during this pandemic. This result also supported by Di Pietro et al. and Herold [30], [35]. They found that adult learners are able to personalize their own learning, they would learn what they like at their own speed and the situation allows them become more flexility during learning activities. The using of Google Classroom in flipped learning during the emergency of this pandemic contributed to the students' autonomously learning or self-directed learning skills due to their taking responsibility by themselves in learning English.

In short, the use of Google Classroom in flipped learning could contribute to the students learning activities during this pandemic. There were several benefits that perceived by the students namely; it can facilitate the students in learning English, increase the students' collaboration and motivation, help the students in understanding the lesson, and develop the students' autonomous learning.

\subsubsection{The challenge of using Google Classroom in flipped learning during the COVID-19 pandemic}

The researcher also found the students' challenges of using Google Classroom in flipped English learning amid the pandemic. Their experiences and responses in using Google Classroom in flipped English learning as follows.

\subsubsection{Limited access to the internet connection}

Regarding to the interview results, some of the students that live in the village or remote areas faced problem with the internet connection. This problem affected their English learning activities during this pandemic. The responses of the students as follows:

"Sometimes the signal in my hometown is disappeared. I must find a place near my home to get high internet connection and download the materials or the videos. When I have online meeting and my internet connection is not stable I cannot practice my English or join the meeting evenly." (Seno, Rantau Prapat, North Sumatera)
"For me, as a student who live in a remote area where the internet connection is not good, sometimes I have to go to other places to get better signal for learning English. Sometimes, I do not have enough time to learn the materials before class meeting and it makes me difficult to discuss with my friends who already understand the lesson. Then, I also need more time to upload or submit my assignment." (Ahmad, Payakumbuh, West Sumatera)

"I think my problem of using Google Classroom in flipped learning is the signal in my hometown is poor. Actually, I really excited to learn English but suddenly the connection is bad and I cannot open Google Classroom easily or participate in class meeting on time. It really affects my motivation in learning English." (Diana, South Lampung)

"I live in a village, sometimes the electricity goes out for several hours. It affects the internet connection too. So, I have to postpone learning the material given by the lecturer. As a result, sometimes I was late in submitting assignment and also missed the class meeting." (Nana, Petapahan, Riau)

Referring to the finding on the challenges of limited of the internet connection above, the researcher assumed that the quality of the internet connection was the crucial factor to the successful of teaching and learning in online flipped learning. This problem also found by another researcher. The study done by Lestiyanawati \& Widyantoro, found that students who lived in suburban areas where there was limited internet access could affect their students' learning processes amid the pandemic [36] Next, Ariyanti found that the students who learned English from their hometown via online learning faced several problems; one of them is the unstable internet connection [37]. This problem disrupted the teaching and learning activities and affected the students' performances.

\subsubsection{Lack of physical interaction}

Based on the interview results, it was found that the students who live in the city did not have problem with their internet connection. They could access Google Classroom and learn English evenly. But, they still preferred to have face to face meeting or offline meeting in the classroom than online flipped learning due to it was lack of physical interaction. The responses of the students as follows:

"I do not have any problems in learning English through Google Classroom. The internet connection in my place is stable and reliable enough to be used for flipped learning. I have unlimited internet access. But, I prefer to learn English face to face in the classroom with my lecturer and my friends because the interaction and the atmosphere are really different. When I learned at campus, I could talk and interact with my lecturer and friends directly. I think even though we have group online discussion but, the feeling is not the same. Sometimes it cannot work as we are expected." (Novri, Pekanbaru, Riau)

"I do not have problems with the application. But, I think the interaction via Google Classroom and flipped English learning is less effective than learning English at 
campus. Because when I interact with the lecturer or my friends, the feel is not as same as when I talk with them directly. It seemed like a gap between us. Sometimes I have misunderstanding in doing my assignment because I cannot ask my lecturer directly about the assignment and I was reluctant to ask my lecturer via chat, I am afraid of bothering my lecturer. I hope we can learn face to face at campus in the next semester." (Abdul, Natuna, Riau Islands)

"During the pandemic, although I can discuss via online but, for me it is not enough to improve my English. I think learning in conventional class at campus is easier and better for improving my English. I feel not satisfied with flipped English learning through Google Classroom because the interaction is not real. However, I must learn from home during this pandemic, I have no option. (Nanda, Belilas, Riau)

Some students mentioned that offline meeting was more effective rather than flipped online learning amid the pandemic. Even though there was interaction using Google Classroom or online meeting, somehow it was not enough. The lack of physically interaction between students and lecturer or student and student could influence their motivation too in learning English. This findings in congruent with Di Pietro et al study that explain the classroom environment affects the students' achievement through peer effects due to the chances to discuss with classmates that produce external motivation [30]. It means that there are emotion and affection needs to achieve an effective teaching and learning process.

\subsubsection{Expensive cost of internet data package}

Next problem was the students complained about the cost of internet data that was expensive for them. Actually, The Ministry of Education and Culture had instructed to the several internet providers and the universities to support students by providing them with free mobile data packages. Nevertheless, the internet data package given to the students was not enough. So, the financial problem also becomes the issue amid the pandemic. The responses of the students as follows:

"I do not have problems with flipped learning and Google Classroom. But, sometimes, I did not have enough money to buy an internet quota. However, the internet quota from the government is not enough. I must work and earn money during this pandemic because my parent lost his job due to the crises of COVID-19 pandemic. So, it makes me late to learn the materials and submit my assignment. Fortunately, my lecturer can accept my situation and give me additional time for learning English. I really hope the government provides more internet data package for us." (NN, Pekanbaru, Riau).

"I think my problem in flipped learning during the pandemic, the internet quota is expensive. It spend around 1,5 -2 GB or IDR 20.000-35.000 in each session for opening Google Classroom, watching lecturer's video and joining the online class meeting. I think it is not economical for the students. But, if we skip using Google Classroom and the flipped learning, we cannot understand the lesson well. So, I hope the government provides us more internet data package for the success of teaching and learning processes during this pandemic." (Laili, Pariaman, West Sumatera)

"I think I seldom have problems with the Google Classroom application in flipped learning, but my problem is the internet quota is expensive." (Candra, Rengat, Riau)

"I do not have problem with the Google Classroom application, but sometimes when I have online meeting, sometimes my internet quota runs out in the middle of meeting and I missed the class. Fortunately, I still can watch my lecturer's video through Google Classroom after I have money to buy the internet quota. However, I missed the discussion session." (Fandi, Pasir Pengaraian, Riau).

\subsubsection{Lack of compatible smartphone}

Next, the students from disadvantaged background or the unprivileged students have low quality of mobile phone or they were lack of the infrastructure for online flipped learning. They explained that their smartphone were not compatible with online learning activities amid the pandemic. The responses of the students as follows:

"My problems in flipped English learning through Google Classroom are my smartphone is not too good. I mean, my parent only can afford to buy the cheap one. So, the features are not complete, the quality is not too good and the storage is not too big. I think my mobile phone is not compatible to flipped learning model. It takes time when I want to access the lecture video, make video assignment and submit my assignments." (AR, Tembilahan, Riau)

"I do not have high technology mobile phone. I cannot easily make or submit my assignment. Sometimes it was broken and I have to borrow my friend's smartphone to make and submit my assignment." Febri, Kuantan Singigi, Riau)

Such findings were congruent with McAleavy et al. who states that the disadvantaged or unprivileged students are less likely to have proper ICT tools and they also have problems in purchasing the internet quota. They also suggested that the government should reduce internet data cost for the disadvantaged students and guarantee free provision of infrastructure namely computer, laptop or tablet for them. So, the students from disadvantaged backgrounds have compatible device and could learn appropriately during this pandemic [38].

\subsubsection{Distraction at home}

The next finding was several students reported that their challenges in online flipped English learning are the distractions at home. It was found that several distractions at home such as noise, housework, and family members that could affect the students' concentration in online flipped learning. This finding is line with Aguilera and Hermida study result who found that the situational and environmental challenges are the biggest challenge for the students in concentrating in online learning during the pandemic [39]. In the interview, the same finding was found by the researcher, as follows: 
"Actually, I do not have any problem about Google Classroom. But, the problem is the activity of online meeting because I cannot focus to do online learning at home because there are distractions at home. First, I have some works to do at home; my parents need my help to do the house works. Second, my little brother is noisy while I am doing online meeting. So, I keep the microphone and the camera off during the online meeting. I also cannot go to internet cafe because many public places providing internet connection are temporarily closed during this pandemic." (Sari, Siak, Riau)

"My problems are the distractions when I am learning from home through Google Classroom in flipped learning. I live with my big family at home. Can you imagine? We must stay at home and learn from home during this pandemic but, my sisters and nephews are so noisy. Then, sometimes there are noises from the passing vehicles or the horns in front of my house. I need a quiet place for studying at home." (Dheni, Batam, Riau Islands)

To sum up all the challenges experienced by the participants in flipped learning through Google Classroom, the researcher concluded that the biggest challenge of having flipped English learning through Google Classroom was the internet connection. After the policy issued by the Ministry of Education and Culture stated that all teaching and learning processes at school should be administered through online learning or distance learning, university students who were not originally from Pekanbaru, decided to go back to their hometown. In fact, many students came from rural areas or remote areas where the internet access was not good since the location of their hometowns are far from the tower and surrounded by mountain, river, or lake that disrupt their internet connection. This condition may result in the students' poor learning activities and motivation. The online learning did not run well as planned and expected. Next, not everyone could afford to purchase the internet data package easily for online learning. Even their parents' income also decreased and some of them must work to help their parents. As a result, several students also could not buy the high-quality smartphone that support their online teaching and learning processes. Finally, lack of physical interaction and many distractions at home while they were learning English via online considered as the students' problems in flipped learning. As for the response to the problems of online learning during this pandemic, it must be said that it was still the best and might be the only option to overcome the university or school closured amid the pandemic.

\section{CONCLUSION}

The findings of this study clearly demonstrated that majority of the students perceived the use Google Classroom in learning English is easy to use, useful, and effective to enhance flipped English learning during the COVID-19 pandemic. Furthermore, the findings asserted that the students have a positive perception of the use of Google Classroom in flipped learning during the pandemic. It was indicated by the means from the students' responses in the questionnaire was categorized as positive level. Based on the results from the interview, there were several benefits of using Google Classroom in flipped English learning found by the researcher namely; it can facilitate the students in learning English, increase the students' collaboration and motivation, help the students in understanding the lesson, and develop the students' autonomous learning. In spite of the benefits on the use of Google Classroom in flipped learning that could contribute the students' teaching and learning processes amid the pandemic, there were also some challenges found by the researcher. Moreover, these issues could impact the students' learning success during the pandemic such as; limited access to the internet connection, lack of physical interaction, expensive cost of internet data package, lack of compatible smartphone, and distractions at home. Nevertheless, even though there were challenges of using Google Classroom in flipped learning still contributed to the students' English learning. Finally, in this unprecedented time which face to face teaching and learning is no longer feasible, the researcher recommended this model to enhance the online learning amid the COVID-19 pandemic. The researcher also hopes other researchers continue conducting next research related to Google Classroom and flipped learning to enhance online learning during the COVID-19 pandemic.

\section{REFERENCES}

[1] Sadeghi, M. 2019. A shift from classroom to distance learning: Advantages and limitation. International Journal of Research in English Education, 80-88.

[2] Roffe, I. 2004. Innovation and E-Learning: Ebusiness for educational enterprise. Cardiff, UK: University of Wales Press.

[3] Singh, V., \& Thurman, A. 2019. How many ways can we define online learning? A systematic literature review of definitions of online learning (1988-2018). American Journal of Distance Education, 33(4), 289-309.

[4] Hartnett, M.K., George A. S.,\& Dron, J. 2011. Examining Motivation in Online Distance Learning Environments: Complex, Multifaceted, and Situation-Dependent. International Review of Research in Open and Distance Learning 12(6): 20-38. Retrieved from: https://www.researchgate.net/publication/2634254 99 Examining Motivation in Online Distance L earning Environments Complex Multifaceted an d Situation-Dependent

[5] Richards, C.A., Vargo, J., \& Seville, E. 2013. Organisational resilience to natural disasters: New Zealand's experience. China Policy Review, 10, 117-119.

[6] Bergmann, J., \& Sams, A. 2012. Flip your classroom: Reach every student in every class every day. Alexandria, Va: International Society for Technology in Education.

[7] Van Alten, D. C.D., Chris, P., Jeroen, j., \& Liestbeth, K. 2019. Effects of flipping the classroom on learning outcomes and satisfaction: A meta-analysis. Educational Research Review 28 (2019) 100281. Elsevier Ltd. 
https://doi.org/10.1016/j.edurev.2019.05.003

[8] Hew, K. F., \& Lo, C. K. 2018. Flipped classroom .,improves students learning in health profession education: meta-analysis. BMC Medical Education, 18(1), 1-12.

https://doi.org/10.1186/s12909-018-1144-Z

[9] Bishop, J. L., \& Verleger, M. 2013. The flipped classroom: A survey of the research. Proceeding of $120^{\text {th }}$ ASEE Annual Conference of the American Society for Engineering Education, 30 (9), 1-18.

[10] Zhang, H. 2019. A flipped classroom-based education system for college English teaching. International Journal of Emerging Technologies in Learning, Vol. 14, No. 16.

https://doi.org/10.3991/ijet.v14i16.11152

[11] Cevikbas, M., \& Ziya, A. 2017. An innovative learning model in digital age: Flipped Classroom. Journal or Education and Training Studies, Vol. 5, No. 11. https://jets.redfame.com

[12] Hamdan, N., Patrick, M., Katherine, M., \& Kari, A. 2013. The flipped learning model: A white paper based on the literature review titled a review of flipped learning. Pearson.

[13] Sparks, S. D. 2011. Education Week: Lecturer are homework in school following Khan Academy Lead. An article. Retrieved from: edweek.org.

[14] Mubarok, A. F., Bambang, Y. C., \& Utari, P. A. 2019. Effect of flipped classroom model on Indonesian EFL students' writing achievement across cognitive styles. Dinamika Ilmu Journal, Vol. 19. No.1. doi:

http: //doi.org/10.21093/di.v19i1.1479

[15] Hung, H.T. 2015. Flipping the classroom for English language learners to foster active learning. Journal of Computer Assisted Learning, 28:1, 8196. https://doi.org/10.1080/09588221.2014.967701

[16] Warman, L.A.D. 2020. The effect of Google Classroom in blended learning on university students' English ability. J-SHMIC: Journal of English for Academic, Vol. 8, No.1.

[17] Al-maroof, R.A.S \& Al-Emran, M. 2018. Students Acceptance of Google Classroom an Exploratory Study Using PLS-SEM Approach. iJET Vol.13, No. 06.

[18] Janzen, M 2014 Hot Team: Google Classroom. Retrieved from http://tlt.psu.edu/2014/12/04/hotteamGoogleclassroom

[19] Syakur, Abd., Sugirin, \& Widiarni. 2020. The effectiveness of English learning media through Google Classroom in higher education. Britain International of Linguistic, Arts, and Education Journal. Vol. 2, No.1.

[20] Creswell, J. W., \& Creswell, J. D. 2018. Research Design: Qualitative, quantitative, and mixedmethod approaches $\left(5^{\text {th }}\right.$ ed). SAGE.

[21] Creswell, J. W., \& Clark, P. V. L. 2011. Designing and conducting mixed-method research $\left(2^{\text {nd }} \mathrm{Ed}\right)$. SAGE Publication Inc.
[22] Venkatesh, V., \& Davis, F. D. 2000. A theoretical extension of the technology acceptance model: Four longitudinal field studies. Management Science, 46(2), 186-204.

[23] Gunduz, N., \& Ozcan, D. 2017. Implementation of the Moodle system into EFL classes. Profile: Issues in Teachers' Professional Development, 19(Suppl.1), 51-64. http://dx.doi.org/10.15446/profile.v19n_sup1.6857 1

[24] Aljaraideh, Y. 2019. Students' Perception of Flipped Classroom: A case study for private universities in Jordan. Journal of Technology and Science Education. https://doi.org/10.3926/jotse.648

[25] Shahani, S., Chalak,A., \& Tabrizi, H.H. 2021. The Iranian Intermediate EFL Learners' Attitudes toward using Flipped Teaching via Google Classroom. Research in English Language Pedagogy. Vol.9 Issue 1. Pp 90-112.

[26] Beaumont, K. 2018. Google Classroom: An Online Learning Environment to Support Blended Learning. Compass: Journal Learning and Teaching. Vol. 11, No.2.

[27] Iftakhar, S. 2016. Google Classroom; What works and how?. Journal of Education and Social Sciences, Vol.3.

[28] Latif, S. 2016. Learning Engagement in Virtual environment. International Journal of Computer Applications, Vol.148., N0. 11, pp.7-13.

[29] Syakur, A. 2019. Application of E-Learning as a method in educational model to increase the TOEFL score in higher education. Journal of Development Research Vo. 3 (2)

[30] Di Pietro, G., Biagi, F., Costa.P., Karpinski Z., Mazza, J. 2020. The likely impact of COVID-19 on education: Reflections based on the existing literatures and recent international datasets, EUR 30275 EN, Publication Office of the European Union, Luxembourg. ISBN 978-92-76-19937-3

[31] Crawford, A. R .2015. Google classroom.

https://acrawf41.weebly.com/...3/7/a-Crawfordemerging-technology

[32] Keeler, A. 2014. 15 more things you can do with Google Classroom. Retrieved from: https://alicekeeler.com/2014/09/22/15-morethings-you-can-do-with-google-classroom/

[33] Schmidt, S. M., \& Ralph, D. L. 2014. The Flipped Classroom: A twist on teaching. The Clute Institute, 98-104.

[34] Cohen, S. \& Brugar, K. 2013. I want that...flipping the classroom. Middle Ground, 16(4), 12-13

[35] Herold, B. 2017. Technology in Education: An overview. Retrieved from:

http://www.edweek.org/ew/issues/technology-ineducation

[36] Lestiyanawati, R., \& Widyantoro, A. 2020. Strategies and problems faced by Indonesian teachers in conducting E-Learning system during 
COVID-19 outbreak. CLLiENT Journal Vol. 2. No.1.

[37] Ariyanti. 2020. EFL students' challenges towards home learning policy during the COVID-19 outbreak. Indonesian Journal of English Language Teaching and Applied Linguistics, Vol. 5(1).

[38] McAleavy, T., Joyness, C., Gibss, E., \& Sims, K. 2020. Report overview of emerging country-level response to providing continuity under COVID-19. What steps are being taken to reach the most disadvantaged students during the period of COVID-19 school closure? Education Development Trust. Retrieved from:

https://edtechhub.org/wpcontent/uploads/2020/09/disadvantagedstudents.pdf

[39] Aguilera, A. P., \& Hermida. 2020. College students' use and acceptance of emergency online learning due to COVID-19. International Journal of Educational Research Open. Elsevier Ltd. 